\title{
Farklı Ham Sığır Gübresi/Mezbaha Atıkları Karışım Oranlarının Biyogaz Üretimi Üzerindeki Etkisinin Araştırılması
}

\author{
Halil ŞENOL ${ }^{1 *}$, Emre Aşkın ELİBOL ${ }^{2}$, Ünsal AÇIKEL ${ }^{3}$, Ali YALÇIN ${ }^{4}$ \\ $I^{*}$ Giresun Üniversitesi, Genetik ve Biyomühendislik Bölümü, Giresun \\ ${ }^{2}$ Giresun Üniversitesi, Makina Mühendisliği Bölümü, Giresun \\ ${ }^{3}$ Cumhuriyet Üniversitesi, Kimya Mühendisliği Bölümü, Sivas \\ ${ }^{4}$ Süleyman Demirel Üniversitesi, Kimya Mühendisliği Bölümü, Isparta
}

\begin{abstract}
$\ddot{\mathbf{O z}}$
Yapılan çalışmada organik atık olan mezbaha atıkları ve sığır gübresi karışımlarından anaerobik fermantasyon ile biyogaz üretilmiştir. Mezbaha atıkları olarak sığır mezbahası atıkları kullanılmıştır. Bu atıklardan kalın bağırsak alınmıştır. Sığır gübresi olarak bütün proseslerde taze sı̆̆ır gübresi kullanılmıştır. Taze sı̆̆ır gübresinin kullanılmasının sebebi ise sığır atığında anaerobik mezofilik bakterilerin mevcut aktif durumda olmasıdır.

Deneyler, $40{ }^{0} \mathrm{C}$ 'de, 500 ml'lik kesikli olarak çalıştırılan nuçe erleninde gerçekleştirilmiştir. Anaerobik fermantasyon işlemlerinden önce, taze sığır gübresi ve mezbaha atıklarının kuru madde ve uçucu organik madde miktarı tayini yapılmıştır. Biyogaz üretimi; sadece sığır atığından, mezbaha atıklarından ve hem sığır hem de mezbaha atıkları karışımlarından üretilmiştir. Anaerobik fermantasyonda gerçekleşen mezbaha atıkları/sığır gübresi karışım oranları 1:0, 1:1, 2:1, 1:2, 0:1 olarak belirlenmiştir. Deneyler 3 tekerrürlü olarak yürütülmüştür. En fazla biyogaz üretimi $353 \mathrm{ml} / \mathrm{g}_{\text {toplam katı madde }}$ olarak 2:1 karışım oranları olan reaktörde ölçülmüştür. Metan oranı ise hacimsel olarak \% 59 olarak belirlenmiştir. Aynı reaktörde ise toplam KOİ giderimi \% 48,45 olarak bulunmuştur. Yapılan bu çalışma sonucunda sığır gübresi ve mezbaha atıklarının iyi bir karışım olabileceği deneysel olarak ispatlanmıştır.
\end{abstract}

Anahtar kelimeler: Biyogaz, Mezbaha Atıkları, Sı̆̆ır Gübresi.

\section{Investigation of the Effect of Different Cattle Manure / Slaughterhouse Waste Mixture Ratios on Biogas Production}

\begin{abstract}
In the study, anaerobic fermentation and biogas were produced from slaughterhouse waste and cattle fertilizer mixture which is organic waste. Slaughter slaughterhouse wastes were used as cattle slaughterhouse wastes A large intestine was used as slaughterhouse waste and fresh cattle manure was used in all processes as cattle manure. The reason for the use of fresh cattle manure is that the anaerobic mesophilic bacteria are presently active in the cattle manure.

Experiments were carried out at a batch reactor of $500 \mathrm{ml}$. The working temperature was chosen to be $40^{\circ} \mathrm{C}$. Prior to the anaerobic fermentation process, the amounts of dry matter and volatile organic matter were determined for fresh cattle manure and slaughterhouse waste. Biogas production is produced exclusively from cattle wastes, slaughterhouse wastes, and mixtures of both cattle manure and slaughterhouse waste. Slaughterhouse waste / cattle manure mixture rates in anaerobic fermentation were determined as $1: 0,1: 1,2: 1,1: 2,0: 1$. The experiments were carried out in 3 recurrence. The maximum biogas production was measured in the reactor with a mixture ratio of 2: 1 as $353 \mathrm{ml} / \mathrm{g}$ VS. The methane content was measured as $59 \%$ by volume. In the same reactor, total
\end{abstract}

\footnotetext{
* Sorumlu yazar: halilsenol1990@hotmail.com Geliş Tarihi: 04/12/2017 Kabul Tarihi: 06/03/2018 Bu çalışma CÜBAP tarafından M-665 nolu proje kapsamında desteklenmiştir.
} 
COD removal was found to $48,45 \%$. As a result of this study, it has been experimentally proven that cattle manure and slaughterhouse waste may be a good mixture.

Keywords: Biogas, Slaughterhouse Waste, Cattle Manure.

\section{Giriş}

Günümüzde enerji ihtiyacı, sanayileșmeyle birlikte doğru orantılı olarak artmaktadır. Bunun sonucunda dünyada artan nüfusla beraber enerji açığı oluşmaktadır. Bu sebeple, tüm Dünya'da enerji ihtiyaçlarını karşılamak için yeni enerji kaynakları aranmaktadır. Aynı şekilde, motorlu taşıtlarda da enerji kaynağı petrol ürünleridir. Petrol kaynaklarındaki olumsuzluklar, alternatif yakıtların kullanımını bir anlamda zorunlu hale getirmektedir [1]. Özellikle büyük yerleşim yerlerinde, havaya bırakılan kirletici gazlar, 1sınma için tüketilen gazlardan daha fazladır. Bu nedenle, motorlu araçlardan kaynaklanan hava kirliliği, çevre sorunu haline gelmiştir [2]. Günlük hayatımızda kullanılan yakıtların oluşturduğu egzoz gazları çevreye zarar vermekte ve zararlı gazların emisyon değerlerini artırmaktadır. Bu durumda yenilenebilir enerjilerin kullanımının artırılması alınabilecek tedbirlerden biridir [3]. Bu nedenlerden dolayı fosil kökenli yakıtların yerini alabilecek alternatif enerji yakıtlarına ihtiyaç vardır [4].

Dünyamız enerji ihtiyacının ortalama; \%33,1'ini petrol, \%30,3 'ünü kömür, \%23,7' 'sini doğal gaz ve \% 5 'ini nükleer enerji olmak üzere toplamda yaklaşık olarak \% 92 'sini, tükenmekte olan enerji kaynaklarından sağlamaktadır. Toplam enerji ihtiyacının yaklaşık \% 8 'i yenilenebilir enerji kaynaklarından sağlanmaktadır [5]. Yenilenebilir enerji kaynaklarından biride biyogazdır.

\subsection{Biyogaz Üretimi}

Biyogaz, biyokütlenin işlenmesi sonucunda elde edilen yanıcı bir gazdır. Biyogaz, yanıcı diğer gazlardan (örneğin doğalgaz) farklı olarak sadece hayvansal veya bitkisel, yani organik hammaddelerden elde edilmektedir. Biyolojik atıklar, gıda sanayii kaynaklı organik atıklar, organik evsel atıklar, mısır veya şeker pancarı gibi enerji bitkileri ile hayvan üretim sonucu oluşan hayvansal dışkılar biyogaz tesislerinde substrat olarak kullanılabilir. Biyogaz organik atıkların belirli oranlarda su ile karıştırılmaları sonucu oksijensiz ortamda (anaerobik fermantasyon) oluşabilen bir gazdır. Biyogazın içeriğinde yaklaşı olarak \% 50-80 metan $\left(\mathrm{CH}_{4}\right)$, \%20-50 karbondioksit $\left(\mathrm{CO}_{2}\right) \%$ 0,1-1 oranında azot $\left(\mathrm{N}_{2}\right)$, \% 0,01-0,2 oranında oksijen $\left(\mathrm{O}_{2}\right)$ ve 10-4000 ppm oranında hidrojen sülfür $\left(\mathrm{H}_{2} \mathrm{~S}\right)$ bulunmaktadır. Biyogazın yanıcılık özelliği doğal gazın yerini tutan metan gazından kaynaklanmaktadır [5].

Biyogaz anaerobik (oksijensiz) ortamda, sabit bir sicaklık altında organik maddelerin farklı mikroorganizma grupları tarafından parçalanmasıyla üretilen bir gaz karışımıdır. Biyogazın doğal oluşumu biyojeokimyasal karbon döngüsünün önemli bir parçasıdır. Metan üreten bakteri familyası (metanojenler) organik maddeyi parçalayarak çevreye ayrışmış ürünler oluşturan mikroorganizmalar zincirinin son halkasından meydana gelmektedir. Bu süreçte yenilenebilir bir enerji olan biyogaz oluşmaktadır. Mikrobiyal faaliyetler nedeniyle doğaya her y1l 500-800 milyon ton metan salınır ve dişarı verilen metanın yaklaşık \%90 '^ biyokütlenin ayrışmasından elde edilir, kalan kısmı ise fosil kökenli kaynaklardan oluşur [6].

Organik maddelerin fermantasyonunun biyokimyasal döngüsü aşağidaki Şekil 1 'de safhalar halinde gösterilmiştir. Bu safhaların ilki hidroliz, ikincisi asit üretimi ve üçüncüsü de metan üretimidir. Birinci safhada yüksek moleküllü organik bileşikler birtakım hücre dışı enzimlerle hidrolize uğrayarak daha küçük molekül ağırlıklı organik bileşiklere dönüşürler. Asit üretimi safhasında düşük molekül ağırlığına dönüşen organik bileşikler asit bakterileri tarafından uçucu yağ asitlerine ve asetik aside dönüştürülür. Üçüncü safhada ise asetik asidin ayrışmasıyla ve $\mathrm{CO}_{2}$ ve $\mathrm{H}_{2}$ senteziyle metan üretimi gerçekleşir [7].

Bu çalışmada biyogaz üretimi mezbaha atıkları ve sığır gübresi karışımlarından yapılmıştır. Afazeli, H., vd., (2014) de yaptıkları bir çalışmada tavuk mezbahası atıklarından biyogaz üretim potansiyeli vurgulanmıştır. Mezbaha atıklarının iyi bir biyogaz kaynağı olabileceği belirtilmiştir [8]. Benzer şekilde Moukazis, I., vd., (2018) yaptıkları bir çalışmada mezbaha yan ürünlerinin biyogaz üretimindeki önemi vurgulanmıştır. Bu çalışmada mide içinde bulunan taze sıvı ve işkembe sıvısı kullanılmıştır [9]. Yine benzer şekilde Ware ve Power (2016) tarafından yapılan bir çalışmada sığır mezbahası atıklarından biyogaz üretilmiştir. Yapılan çalışmanın sonucuna göre toplam biyogaz miktarının, ülkenin elektrik 
ihtiyacı giderimi için anlamlı derecede olduğu ve biyogaz üretimi için mezbaha atıklarının kullanımının göz ardı edilmemesi vurgulanmıştır [10].

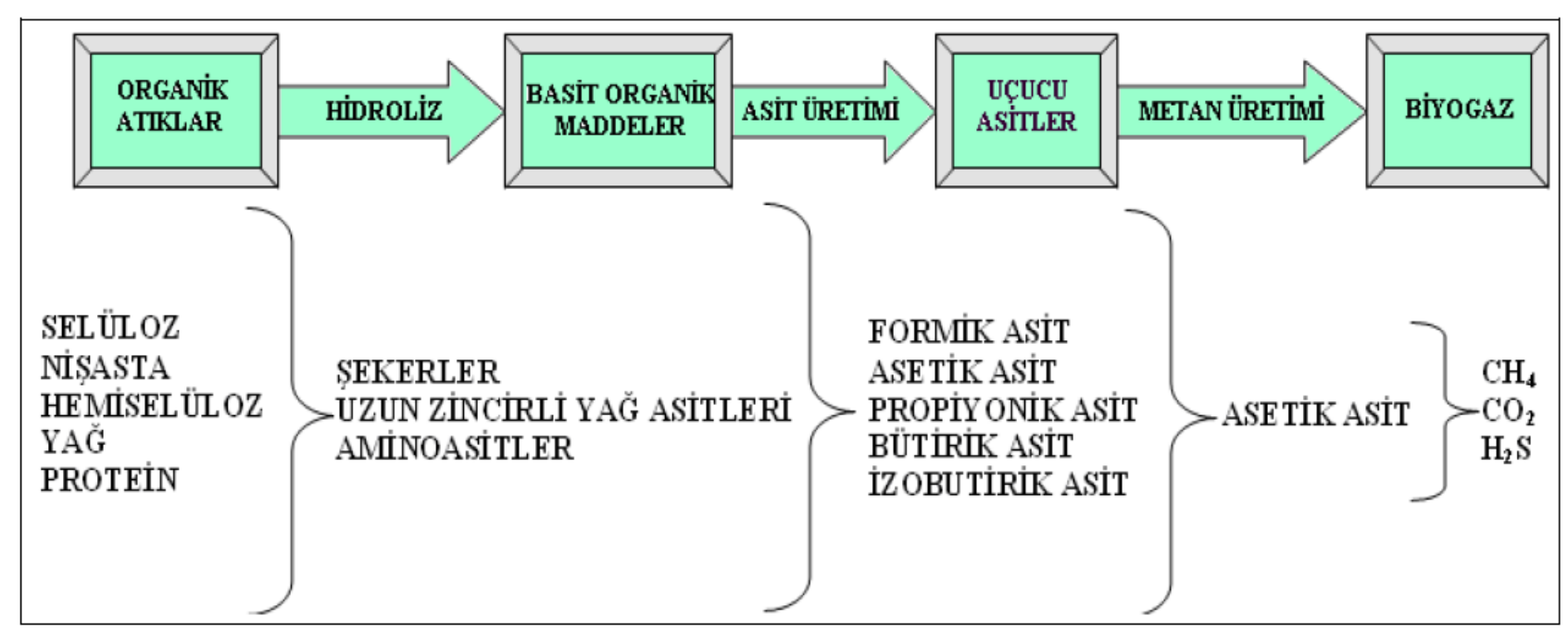

Şekil 1. Biyogaz üretiminin biyokimyasal şekli

\subsection{Hesaplamalı Akışkanlar Dinamiği (HAD)}

Computational fluid dynamics (CFD) olarak bilinen, hesaplamalı akışkanlar dinamiği (HAD) yazılımları ilk olarak 1960 'lı yıllarda kullanılmaya başlanmıştır. Günümüzde, CFD yazılımları, tasarım sürecinin kısaltılması ve üretim maliyetinin azaltması bakımından yoğun şekilde kullanılmaktadır. Ayrıca, tasarım sonrası imal edilen prototipler üzerinde, çok sayıda deney yapılması ve yine çok sayıda güvenlik önlemleri alınması, özellikle büyük sistemlerde çok zor ve maliyetli bir işlemdir. Bu çalışma ile ilgili olarak CFD analizi tanımlanacak olursa; akış ve ısı transferi açısından problemin analitik olarak çözülmesi mümkün değildir. Bu nedenle, reaktör içindeki akış davranışı ve 1sı transferi incelenirken hazır CFD paket programı kullanılmıştır [11].

Jalilnejad ve Amani (2017) yaptıkları bir çalışmada adsorpsiyon kolonunda yapılan biyogaz adsorplama işlemleri sayesinde CFD programı kullanarak sıcaklığın etkisini 3 boyutlu olarak gözlemlemişlerdir. Aynı şekilde buna benzer bir çalışmayı Xuan J. vd., (2009) yapmıştır [12,13]. Fakat 1sı kayıplarının incelendiği çalışmalar yok denecek kadar azdır. Ancak maliyeti en aza indirmenin ön önemli yollarından biride, 1sı kayıplarının en aza indirilmesi gerçeğidir.

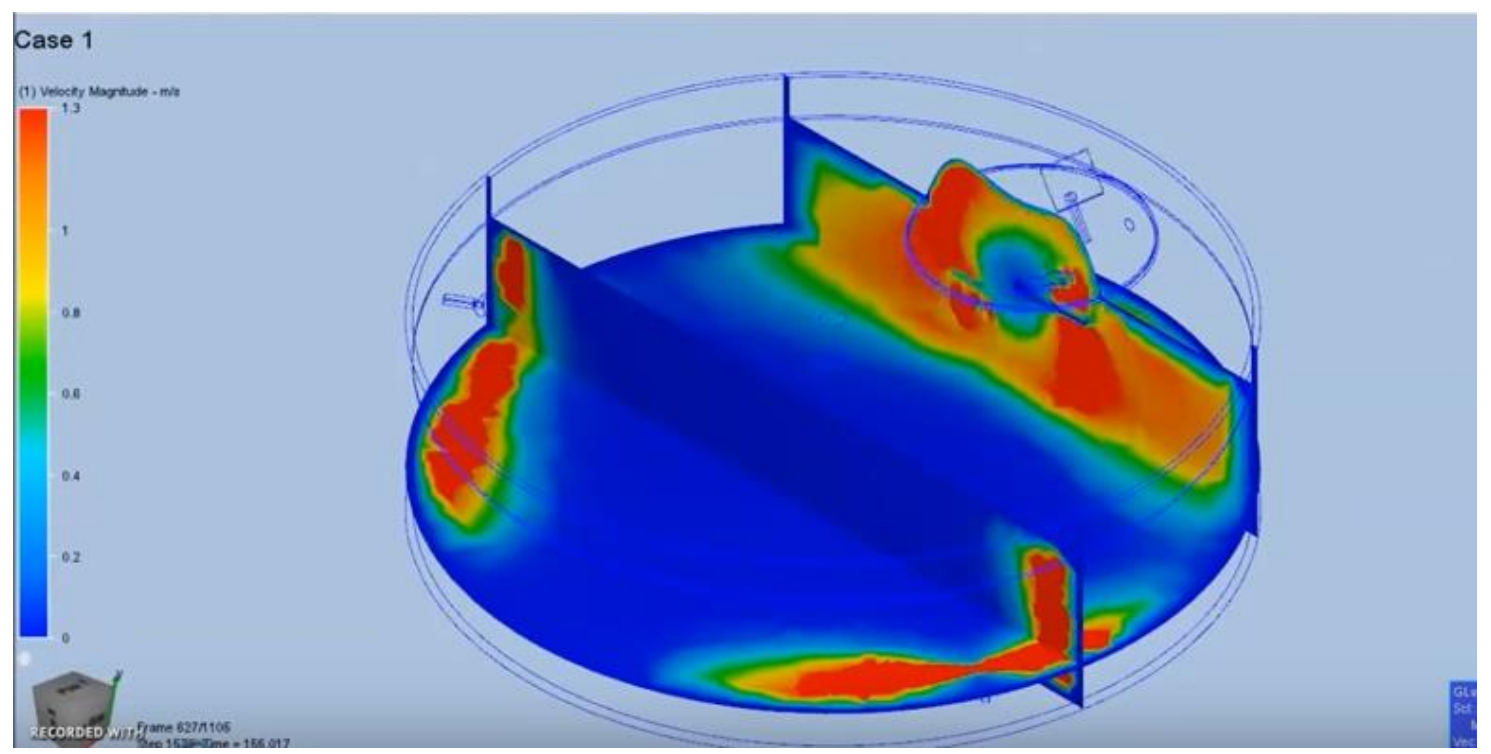

Şekil 2.CFD programının biyogaz reaktöründeki karıştırıcı etkisinin görsel olarak tanımlanması [14]. 
Yukarıdaki şekilde, bir çalışmada, biyorektörün içerisine yerleştirilmiş karıştırıcının reaktör içindeki akış davranışına etkisi simüle edilmiştir. Hız dağılımı incelendiğinde, biyoreaktörün orta kısımlarında akışkan hızının düşük olduğu (karıştırıcı etkisinin az olduğu), karıştırıcı çarklarına yaklaşan kısımda ise akışkan hızının arttığı (karıştırıcının en etkili olduğu kısım) görülmektedir. Bu nedenle özellikle büyük kapasiteli tesislerde karıştırıcı çarklarının ayarlanmasında veya aynı şekilde optimum ısıtıcının ve 1sı kayıplarının da buna benzer şekilde incelenmesi reaktör için optimum verimlilik ve minimum maliyet sağlamaktadır [14].

\section{Materyal ve Metot}

\subsection{Taze Sığır Gübresi ve Mezbaha Atıklarının Kuru Madde Analizleri}

Toplanan numunelerin her birinden hassas terazide 5 gram tartılarak, etüvde $105{ }^{\circ} \mathrm{C}$ 'de içerisinde nem kalmayacak şekilde 24 saat kurutulmuştur. Kurutma işlemi porselen krozede yapılmıştır. Öncelikle porselen kroze etüvde $105^{\circ} \mathrm{C}$ 'de 1 saat boyunca içerisinde hiç nem kalmayacak şekilde kurutulup daras1 alınmıştır. Kurutulan bu numuneler tekrar tartılarak kuru madde oranı belirlenmiştir. Daha sonra bu tartımı alınmış kuru numunelerin her biri ayrı ayrı porselen krozeye konularak kül fırında $600{ }^{\circ} \mathrm{C}$ 'de 2,5-3 saat bekletilmiştir. $\mathrm{Bu}$ şekilde $600{ }^{\circ} \mathrm{C}$ de bütün organik maddeler yanarak uçtuğundan dolayı geriye kalan kül gravimetrik olarak tartılarak uçucu organik madde miktarı \%ağırlık olarak belirlenmiştir $[15,16]$.

\subsection{Anaerobik fermantasyon işlemleri}

Kuru madde optimizasyon deneyleri için deney sistemi kurulmuş olup, numuneler; 1:0, 1:1, 2:1, 1:2, 0:1 oranında karıştırılmıştır. Toplamda her biri üç tekerrürlü olmak üzere, toplam kuru madde oranı $\% 10$ olacak şekilde 500 ml'lik 15 adet nuçe erlenlerine biyogaz oluşumu için deney sistemi kurulumu yapılmıştır. Nuçe erlenlerinin çıkış borusuna göre hortum ve bu hortumun diğer ucuna da 0,5 litrelik gaz toplama torbaları eklenerek ardından nuçe erlenleri alüminyum folyo ile kaplanmıştır. Nuçe erlenlerinin bütün deneylerde \%80 'i (400 ml) substrat ve su karışımıyla doldurulup ve \%20 'si boş bırakılmıştır. Sistemde olası bir gaz kaçağının olmaması için hortumlarının giriş ve çıkışı bantlanmıştır. Oksijensiz fermantasyon düzeneği bu şekilde kurulduktan ve reaktörlerin içerisi kuru madde oranına göre ayarlandıktan sonra her bir numuneye aşı (taze sığır gübresi) belirli şartlarda eklenmiştir. Oksijensiz karanlık fermantasyon işlemi için her bir reaktörün $\mathrm{pH}$ ölçümü yapılmış ve ardından eğer $\mathrm{pH}$ biyogaz oluşumda metan bakterilerinin üremesi için gerekli şartlar olan 6,6-7,6 değerinde değilse $\mathrm{pH}$ bu aralıktaki gelene kadar hazırlanan $8 \mathrm{M} \mathrm{NaOH}$ ve $8 \mathrm{M} \mathrm{H}_{2} \mathrm{SO}_{4}$ tamponları ile ayarlanmıştır. Isıtma işlemi dış ortam sıcaklığı olarak $40{ }^{\circ} \mathrm{C}$ olarak seçilmiştir. Deneyler üç tekerrürlü olarak yürütülmüştür. Isıtma işlemi alttan 1sıtılan sabit karıştırmalı 1sıtıcılar yardımıyla yapılmıştır. Yaklaşık 6 saatte bir 3 dakika reaktörlerin manuel olarak karıştırılması sağlanmıştır. Biyogaz üretimi gaz oluşumu durana kadar devam etmiştir. Sonuç olarak, kuru maddenin gaz oluşum kapasitesi $\mathrm{ml}$ biyogaz/g $\mathrm{g}_{\text {U̧̧ucu katı }}$ olarak belirlenmiştir ve zaman-metan üretimi grafiği oluşturulmuştur. Metanojen bakterilerin 1şığa duyarlı olmasından dolayı, biyogaz üretim aşamasında reaktörlerin her biri alüminyum folyo ile sarılarak reaktörlerin 1şık geçirgenliği yok edilmiştir [17]. Gerekli fermantasyon 65 gün sürmüştür. 65. gün anaerobik süreç durduğundan biyogaz miktarı ve içeriği \% hacimsel olarak tayin edilmiştir.

\subsection{KOİ Tayinleri}

KOİ, evsel ve endüstriyel atık suların kirlilik derecesini belirlemede kullanılan önemli bir parametredir ve kimyasal oksidasyonda maddenin biyolojik olarak ayrışıp ayrışmadığına ve ayrışma hızına bakılmaksızın bütün organik maddelerin oksitlenebilme kapasitesini temsil eder. Kimyasal oksijen ihtiyacı çevre kirlenmesinde en çok kullanılan parametrelerdendir. Atık suların bünyesindeki organik maddelerin miktarının, kimyasal oksidasyonları için gerekli oksijen miktarı cinsinden belirlenebilmesi ile elde edilebilen bir metottur. Yöntem birkaç istisna dişında tüm organik maddelerin, kuvvetli oksitleyicilerle asit ortamlarda oksitlenebilecekleri esasına dayanmaktadir [18]. Anaerobik fermantasyondaki bütün KOİ tayinleri APHA standart metotlara göre yapılmıştır [15]. 


\section{Bulgular ve Tartışma}

Anaerobik fermantasyona başlamadan önce sığır gübresi atığına birtakım analizler yapılmıştır. Bu analizler aşağıdaki Tablo 1 'de gösterilmektedir.

Tablo 1: Sığır gübresi atığına uygulanan birtakım analiz sonuçları

\begin{tabular}{lcc}
\hline & \multicolumn{2}{l}{ Anaerobik } \\
Parametreler & $\begin{array}{l}\text { Anaerobik } \\
\text { Önceki Değerler }\end{array}$ & $\begin{array}{l}\text { Fermantasyondan } \\
\text { Sonraki Değerler }\end{array}$ \\
\hline$\%$ nem & 89,12 & 88,23 \\
$\%$ toplam kuru madde & 10,72 & 9,65 \\
$\mathrm{pH}$ & 7,25 & 7,61 \\
$\begin{array}{l}\text { \% Uçucu katı maddem } \\
\text { miktarı }\end{array}$ & 8,57 & 8,01 \\
\hline
\end{tabular}

Yukarıdaki Tablo 1 'de sadece sığır gübresinin anaerobik fermantasyona başlamadan önce nem tayini, toplam kuru madde tayini, pH ölçümü ve uçucu organik madde miktarı tayini yapılmıştır.

Tablo 2: Mezbaha atıklarına uygulanan birtakım analiz sonuçları

\begin{tabular}{|c|c|c|}
\hline \multirow{3}{*}{ Parametreler } & Anaerobik & Anaerobik \\
\hline & Fermantasyondan & Fermantasyondan \\
\hline & Önceki Değerler & Sonraki Değerler \\
\hline$\% \mathrm{Nem}$ & 87,05 & 86,56 \\
\hline$\%$ Toplam kuru madde & 12,62 & 9,61 \\
\hline $\mathrm{pH}$ & 7,75 & 7,58 \\
\hline Kül (\% KM) & 14,71 & 15,28 \\
\hline $\begin{array}{l}\text { \% Uçucu Kuru Madde } \\
\text { Miktarı }(\% \text { KM })\end{array}$ & 9,67 & 8,00 \\
\hline $\mathrm{C} / \mathrm{N}$ & 15,28 & 28,52 \\
\hline
\end{tabular}

Yukarıdaki tablo 2 'de sadece mezbaha atıklarının anaerobik fermantasyona başlamadan önce nem tayini, toplam kuru madde tayini, pH ölçümü ve uçucu organik madde miktarı tayini yapılmıştır.

$\mathrm{Bu}$ sonuçlara göre anaerobik fermantasyon sonrasında organik madde miktarının ve uçucu organik madde miktarının payında azalma gözlemlenmiştir. Ayrıca aynı mezbaha atıklarındaki $\mathrm{pH}$ artmış ve sığır gübresi fermantasyonunda $\mathrm{pH}$ ise azalmıştır. Bununla birlikte aynı şekilde toplam nem içeriği de azalmıştır.

\subsection{Anaerobik proses boyunca CFD analizlerinin uygulanması}

Reaktör içindeki sıcaklık dağılımı ve hız (akım) çizgileri çıkarılarak gözlemlenmiştir. Isıtılan reaktörde, 1sı kayıpları belirlenerek 1sıtma derecesi görsel olarak incelenmiştir. Bu bölümde su banyosunda 
kullanılacak olan su seviyesinin küçük 500 ml'lik nuçe erlenlerinin 400 ml'sine kadar doldurularak alt tabakadan düz bir plaka ile ısıtma sağlanmıştır. Bu nedenle, reaktördeki 1sı ihtiyacı karşılanırken, su banyosunda 1sıtma etkilerinin hesaplanmasına yönelik gerekli olan sıcaklık dağılımları incelenmiştir ve 1sı aktarımının şekli belirlenmiştir.

Nuçe erleni içinde 400 ml'lik içerisinde \%10 katı madde içeren gübre su karışımı bulunmaktadır. Cam reaktörün yüzeyleri adyabatik olarak kabul edilmiştir. Nuçe erleninin boş kalan kısmı durgun havadan oluşmaktadır. Problem silindirik koordinatlarda iki boyutlu olarak incelenmiştir. Nuçe erleninin çıkış boynu atmosfer basıncına açıktır. Nuçe erleninin alt kısmında sabit sıcaklık sınır şartı $40{ }^{\circ} \mathrm{C}\left(313{ }^{\circ} \mathrm{K}\right)$ tanımlanmıştır. Doğal konveksiyon koşulunda, enerji denklemi çözülerek erlen içindeki gübre hacminin sıcaklık dağılımı elde edilmiştir. Doğal konveksiyon koşulunda, Boussinesq modeli esas alınmıştır. Problemi çözerken kullanılan korunum denklemleri (süreklilik, momentum, enerji) sırasıyla aşağıdaki gibi ifade edilmiştir.

$$
\begin{aligned}
& \frac{1}{r} \frac{\partial(\mathrm{ru})}{\partial \mathrm{r}}+\frac{\partial \mathrm{v}}{\partial \mathrm{z}}=0 \\
& \mathrm{u} \frac{\partial \mathrm{u}}{\partial \mathrm{r}}+\mathrm{v} \frac{\partial \mathrm{u}}{\partial \mathrm{z}}=-\beta \mathrm{g}\left(\mathrm{T}-\mathrm{T}_{\infty}\right)-\frac{1}{\rho_{\infty}} \frac{\partial}{\partial \mathrm{r}}\left(\rho-\rho_{\infty}\right)+v\left(\frac{\partial}{\partial \mathrm{r}}\left(\frac{1}{\mathrm{r}} \frac{\partial}{\partial \mathrm{r}}(\mathrm{ru})\right)+\frac{\partial^{2} \mathrm{u}}{\partial \mathrm{z}^{2}}\right) \\
& \mathrm{u} \frac{\partial \mathrm{v}}{\partial \mathrm{r}}+\mathrm{v} \frac{\partial \mathrm{v}}{\partial \mathrm{z}}=-\frac{1}{\rho_{\infty}} \frac{\partial}{\partial \mathrm{z}}\left(\rho-\rho_{\infty}\right)+v\left(\frac{1}{\mathrm{r}} \frac{\partial}{\partial \mathrm{r}}\left(r \frac{\partial \mathrm{v}}{\partial \mathrm{r}}\right)+\frac{\partial^{2} \mathrm{v}}{\partial \mathrm{z}^{2}}\right) \\
& \mathrm{u} \frac{\partial \mathrm{T}}{\partial \mathrm{r}}+\mathrm{v} \frac{\partial \mathrm{T}}{\partial \mathrm{z}}=\alpha\left(\frac{1}{\mathrm{r}} \frac{\partial}{\partial \mathrm{r}}\left(r \frac{\partial \mathrm{T}}{\partial \mathrm{r}}\right)+\frac{\partial^{2} \mathrm{~T}}{\partial \mathrm{z}^{2}}\right)
\end{aligned}
$$

Burada:

r ve z yönleri; u, r-yönündeki hızı; v, z-yönündeki hızı; $v$, kinematik viskoziteyi; $\alpha$, 1sı yayınım katsayısını; $\rho$, yoğunluğu; $\beta$, 1sıl genleşme katsayısını ifade etmektedir.

Verilen parametre ve korunum denklemlerine göre simülasyonlar yapılmıştır. Bu denklemler yukarıda (1), (2), (3) ve (4) olacak şekilde ifade edilmiştir. Elde edilen sıcaklık dağılımı aşağıdaki şekil 3 'de gösterilmektedir.

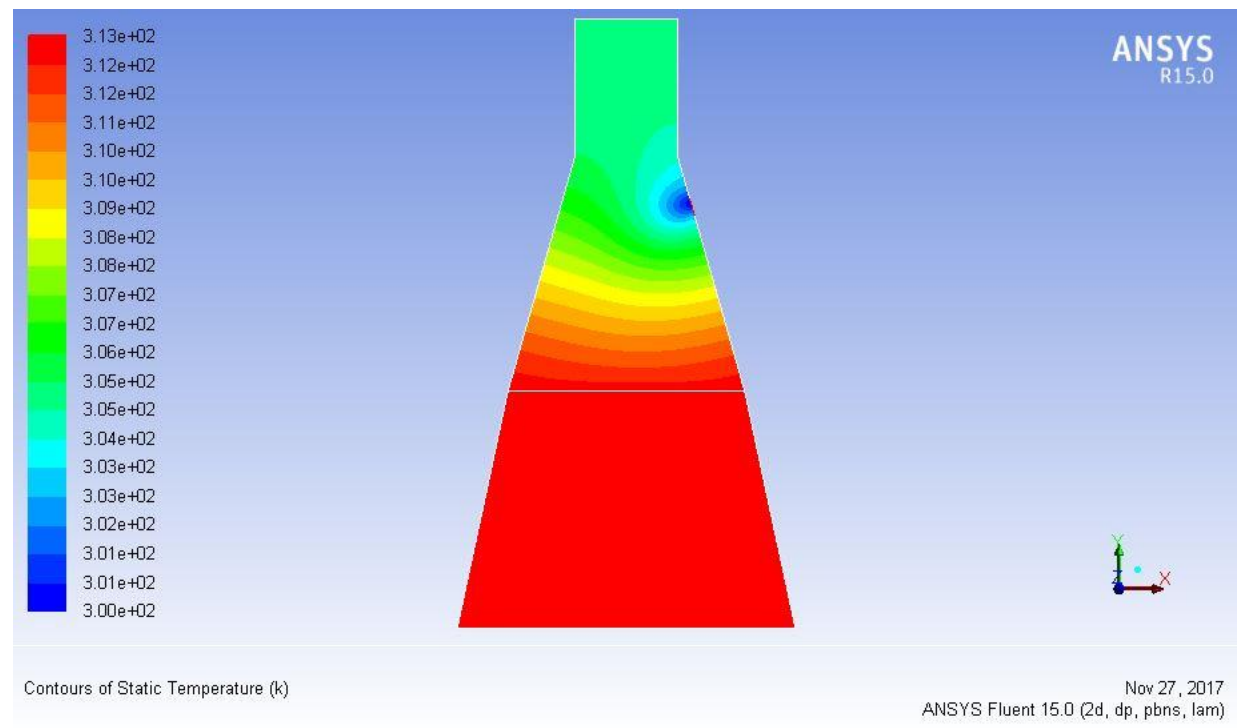

Şekil 3: Anaerobik reaktörün sıcaklık dağılımının 2 boyutlu gözlemlenmesi

Sicaklık dağılımı incelendiğinde, gübre-hava ara yüzeyinin $1,2 \mathrm{~cm}$ üzerinden itibaren $(\mathrm{y}=8,2 \mathrm{~cm})$ 1S1 kayıpları oluşmaya başladığı ve biyoreaktör üst kısmı ile çıkış boynunda $300-309{ }^{0} \mathrm{~K}$ arasında sıcaklık dağılım skalasının mevcut olduğu görülmektedir. Sonuç olarak, biyoreaktör içindeki gübrenin verilen hacminde 1sı kaybı yaşanmamakta ancak, sabit sıcaklık sınır şartı yerine sabit ısı akısı koşulunda daha homojen bir dağılım elde edilebilir. 


\subsection{Anaerobik Prosesler Boyunca Oluşan Gaz Hacimlerinin Belirlenmesi}

Gaz torbasından küçük bir pompa ile alınan gaz numuneleri biyogaz analiz cihazından geçirilerek biyogaz içeriği belirlenmiştir.

Tablo 3: Organik atıkların \%hacimsel gaz içerikleri

\begin{tabular}{llllll}
\hline $\begin{array}{l}\text { Mezbaha } \\
\text { Atıkları/Sı̆̆ır } \\
\text { Gübresi }\end{array}$ & $\begin{array}{l}\mathbf{C H}_{\mathbf{4}} \\
(\mathbf{\%})\end{array}$ & $\begin{array}{l}\mathbf{C O}_{2} \\
(\boldsymbol{\%})\end{array}$ & $\begin{array}{l}\mathbf{O}_{\mathbf{2}} \\
(\mathbf{\%})\end{array}$ & $\begin{array}{l}\mathbf{N}_{\mathbf{2}} \\
(\boldsymbol{\%})\end{array}$ & $\begin{array}{l}\mathbf{H}_{2} \mathbf{S} \\
(\mathbf{p p m})\end{array}$ \\
\hline $1: 0$ & 58.2 & 41.3 & 0,050 & 0,26 & 303 \\
$1: 1$ & 55.3 & 44.2 & 0,075 & 0,29 & 305 \\
$1: 2$ & 59.4 & 40.0 & 0,089 & 0,38 & 362 \\
$2: 1$ & 57.6 & 41.5 & 0,079 & 0,55 & 309 \\
$0: 1$ & 56.9 & 42.3 & 0,064 & 0,62 & 298 \\
\hline
\end{tabular}

Yukarıdaki tablo 3 incelendiğinde en yüksek metan içeriği yine en yüksek gaz içeriğine sahip 1:2 oranındaki reaktörden sağlanmıştır.

\subsection{Oluşan Gaz Hacimleri}

Tablo 4 'de görüldüğü gibi, belirlenen oranlarda karıştırılan sığır gübresi/mezbaha atıkları karışımlarının biyogaz miktarları ve metan miktarları verilmiştir. Yine metan üretim hızı en fazla $203,3 \mathrm{ml} / \mathrm{g}_{\text {uçucu katı }}$ olarak belirlenmiştir.

Tablo 4: Organik atıkların biyogaz ve metan verimleri

\begin{tabular}{|c|c|c|}
\hline $\begin{array}{l}\text { Mezbaha } \\
\text { Atıkları/Sı̆̆ır Gübresi }\end{array}$ & $\begin{array}{l}\text { Biyogaz oluşum } \\
\text { kapasitesi } \\
\left(\mathrm{ml} / \mathrm{g}_{\text {uçucu katı }}\right)\end{array}$ & $\begin{array}{l}\mathrm{CH}_{4} \text { oluşum } \\
\text { kapasitesi } \\
\left(\mathrm{ml} / \mathrm{g}_{\text {uçucu katı }}\right)\end{array}$ \\
\hline $0: 1$ & 250 & 145,5 \\
\hline $1: 1$ & 322 & 178,0 \\
\hline $1: 2$ & 302 & 179,4 \\
\hline $2: 1$ & 353 & 203,3 \\
\hline 1:0 & 278 & 158,1 \\
\hline
\end{tabular}

\subsection{KOİ Analizi Sonuçları}

Deneylerde KOİ analizleri 1:0, 0:1 ve en yüksek verimi sağlayan 1:2 oranlarını içeren reaktörler için yapılmış ve sonuçlar grafik 1, grafik 2 ve grafik 3 'de gösterilmiştir. KOİ analizleri nuçe erleninin çıkış kısmından küçük bir enjeksiyon şırıngası sokularak reaktörün içerisinde bulunan sulu karışımdan 1 gram örnek alınarak yapılmıştır. 


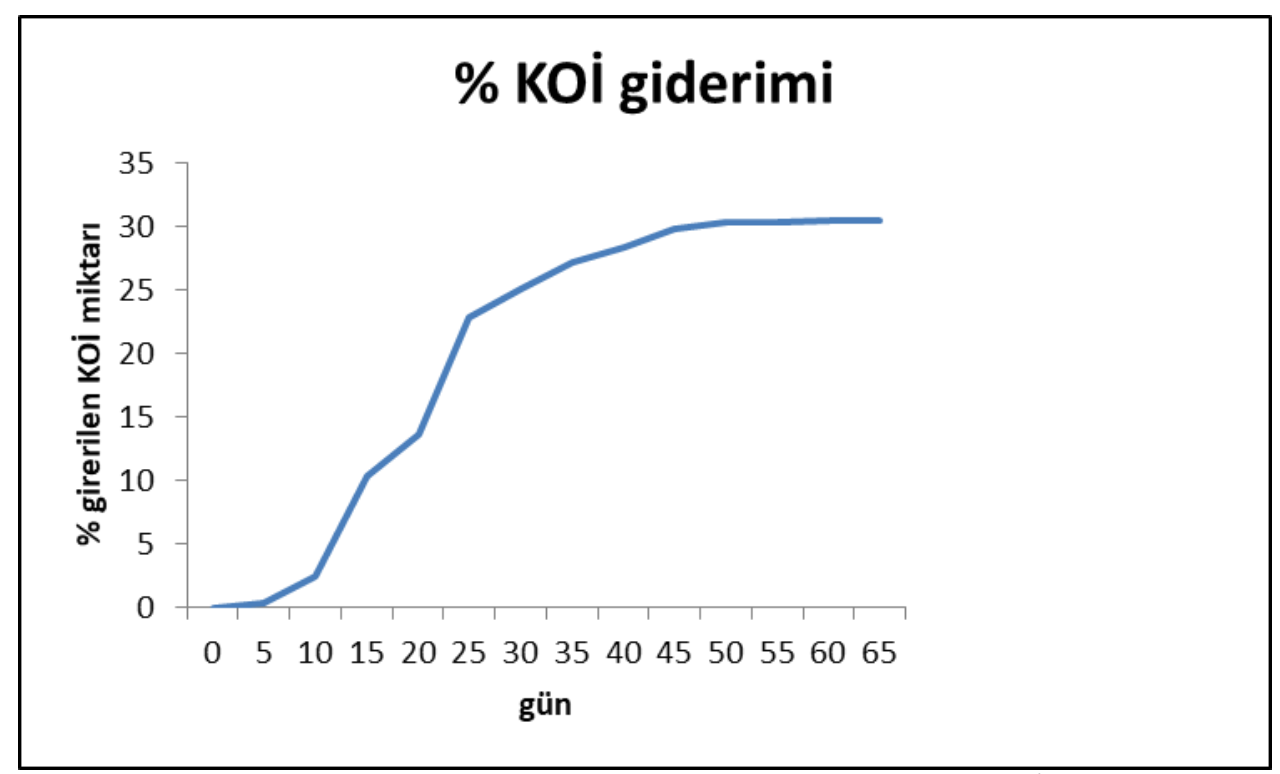

Grafik 1. Sığır Atığının Anaerobik Fermantasyondaki \% KOİ Giderimi

Yukarıdaki grafik 1 anaerobik reaktörde \%10 katı madde içeren ve 1:0 oranında karıştırılan organik sığır gübresi için yapılan analizlerden elde edilmiştir. Anaerobik fermantasyon süresi 65 gün sürmüş ve toplam KOİ giderimi ise $\% 30,54$ olmuştur.

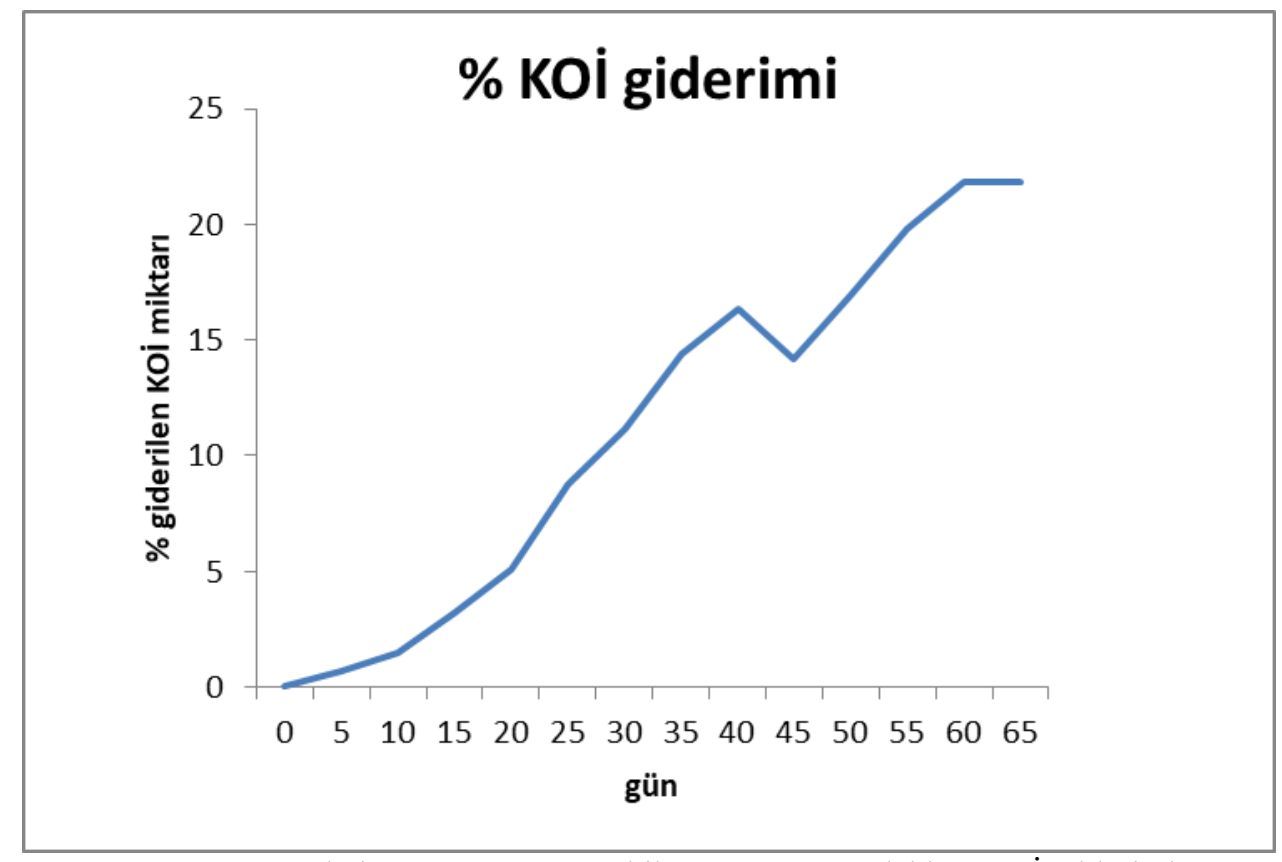

Grafik 2. Mezbaha Atığının Anaerobik Fermantasyondaki \% KOİ Giderimi

Yukarıdaki grafik 2, anaerobik reaktörde \%10 katı madde içeren ve 0:1 oranında karıştırılan organik mezbaha atığı için yapılan analizlerden elde edilmiştir. Anaerobik fermantasyon süresi 65 gün sürmüş ve toplam KOİ giderimi ise \% 21,82 olmuştur. Anaerobik proseslerde biyogaz üretiminin verimli olabilmesi için toplam giderilen KOİ 'nin en az \%30 olması gerekmektedir. Bu sonuçlar tek başına mezbaha atıkları için anaerobik proseslerin KOİ giderimi açısından verimsiz olduğunu göstermektedir. 


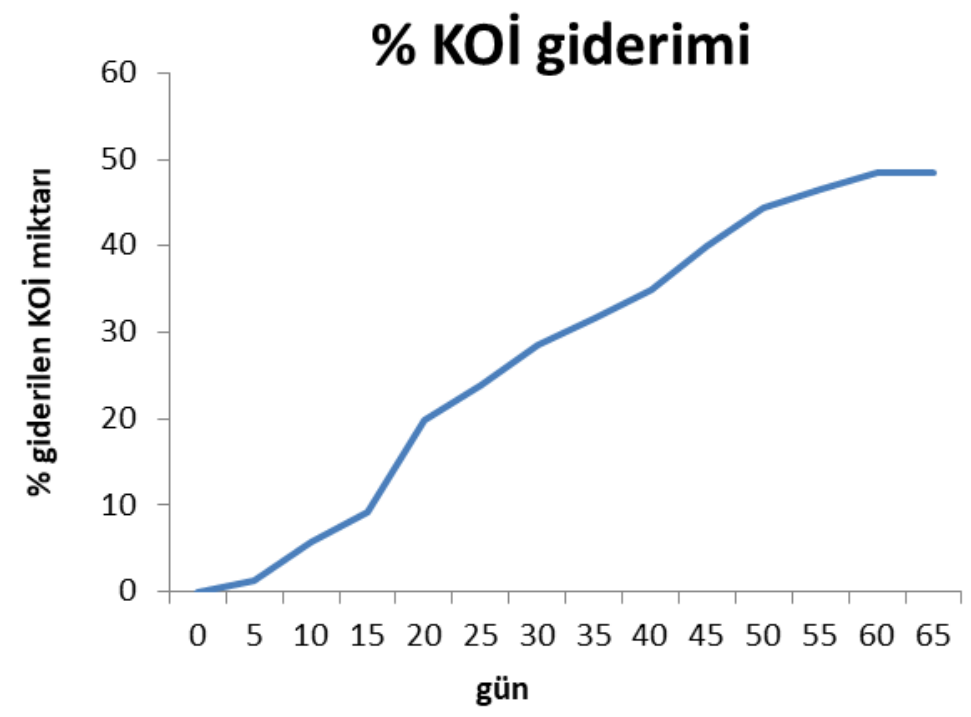

Grafik 3. Sığır Atığının ve mezbaha atıklarının 1:2 oranında karıştırılan reaktördeki \% KOİ Giderimi

Yukarıdaki grafik 3, \%10 katı madde içeren ve 1:2 oranında karıştırılan organik sığır gübresi ve mezbaha atığ için yapılan analizlerden elde edilmiştir. Anaerobik fermantasyon süresi 65 gün sürmüş ve toplam KOİ giderimi ise $\% 48,45$ olmuştur.

Mouzakis vd., mezbaha atıklarından biyogaz üretim çalışmalarında üretilen metan miktarı gram uçucu katı başına 815, 787 ve $759 \mathrm{ml}$ olarak bulunmuştur. Bu değerler bizim çalışmada bulunan değerlerin yaklaşı 2,3 katı civarındadır. Fakat Mouzakis vd. mezbaha atıklarına anaerobik fermantasyon uygularken termal önişlem uygulamışlardır. [9] Biyogaz teknolojilerinde kullanılan önişlemler verimi artırmasına rağmen maliyetli olduğundan yaygınlaşmadığı aşikardır[19].

Rodríguez-Abalde vd., yaptıkları çalışmada domuz gübresi ve mezbaha atıklarından biyogaz üretimi gerçekleştirilmiştir. En yükssek metan üretimi ise gram uçucu katı başına $640 \mathrm{ml}$ metan üretimi gerçekleştirilmiştir. Fakat bu üretim kesikli reaktörde değil, sürekli karıştırmalı tank reaktörde gerçekleştirilmiştir. Sonuç olarak üretim denemelerinde toplam üretim süresi 490 gün ve alıkonma süresi ise 21-33 gün olarak belirlenmiştir [20].

\section{Sonuç ve Öneriler}

$\mathrm{Bu}$ araştırmada, organik atıklar olan sığır gübresi ve mezbaha atıklarından biyogaz üretimi yapılmıştır. Anaerobik fermantasyonda birden fazla organik atıkların beraber değerlendirilmesi işlemine kofermantasyon denilmektedir. Bu projede ise mezbaha atıkları ile sığır gübresinin kofermantasyonu anaerobik süreç boyunca incelenmiştir. Anaerobik fermantasyonda tek organik atıkla çalış1ırken biyogaz veriminin düşük olduğu bilinmektedir. Bu sonuç çalışmamızda da kanıtlanmıştır. Mezbaha atıklarının tek başına biyogaz üretimi $250 \mathrm{ml} / \mathrm{g}_{\text {uçucu katı }}$ iken sığır gübresinin tek başına $\% 10$ katı madde içeren biyogaz üretimi $278 \mathrm{ml} / \mathrm{g}_{\text {uçucu katı }}$ 'dır. Bununla birlikte, bu iki organik atıkla anaerobik süreç incelendiğinde en ideal mezbaha atığı/sığır gübresi karışım oranı 2:1 olarak bulunmuştur ve karışımın biyogaz üretim verimi $353 \mathrm{ml} / \mathrm{g}_{\text {uçucu katı }}$ olarak belirlenmiştir. Bu sonuçlardan elde edilen verilere göre, mezbaha atıkları ve sığır gübresi ile biyogaz üretimi yapılırken, en ideal karışım oranının 2:1 olduğu tespit edilmiştir. 


\section{Kaynaklar}

1. Tüter B. 2007. Alternatif Yakıtların Dizel Motorlarda Kullanımı Teknik Ve Ekonomik Analizi. Yıldız Teknik Üniversitesi, Fen Bilimleri Enstitüsü, Yüksek lisans tezi, İstanbul.

2. Demir İ., Öztürk İ. 1989. Havasız Çamur Yataklı Reaktörlerin Kinetik Modellenmesi, 5. Çevre Bilimleri ve Teknolojisi Kongresi, Çukurova Üniversitesi, Adana.

3. Jorach R., Enderle C., Decker R. 1997. Development of low-NOx truck hydrogen engine with high specific power output, Int. J. of Hydrogen Energy, 22 (4): 423-427.

4. Batmaz İ. 2007. Buji ateşlemeli motorlarda yakıta hidrojen ilavesinin motor performansına ve egzoz emisyonlarına etkisinin deneysel analizi, Gazi Üniversitesi Müh. Mim. Fak. Dergisi, 22: 16.

5. Koçar G., Eryaşar A., Ersöz Ö., Arıcı Ş., Durmuş A. 2010. Biyogaz teknolojileri, Ege Üniversitesi Basımevi, İzmir.

6. Öztürk M. 2005. Hayvan Gübresinden Biyogaz Üretimi. Çevre ve Orman Bakanlığ1, Ankara.

7. Kossmann W., Pönitz U. 1999. Biogas Digest, 'Biogas Basics Volume I, Informationand Advisory Service on Appropriate Technology (ISAT)", GATE in DeutscheGesellschaft für Technische Zusammenarbeit (GTZ), GmbH, Eschborn, FederalRepublic of Germany.

8. Afazeli H., Jafari A., Rafiee S., Mohsen Nosrati M. 2014. An investigation of biogas production potential from livestock and slaughterhouse wastes, Renewable and Sustainable Energy Reviews, 34 (2014): 380-386.

9. Moukazis I., Pellera F., M. Gidarakos E. 2018. Slaughterhouse by-products treatment using anaerobic digestion, Waste Management, 71: 652-662.

10. Ware A., Power N. 2016. Biogas from cattle slaughterhouse waste: Energy recovery towards an energy self-sufficient industry in Ireland, Renewable Energy, 97: 541-549.

11. Elibol E.A. 2017. Gözenekli Düz Bir Yüzeye Çarpan Jetin Sayısal Olarak İncelenmesi. Gazi üniversitesi, Fen Bilimleri Enstitüsü, Yüksek lisans tezi, Ankara.

12. Xuan J., Michael K.H., Leung D., Dennis Y.C., Leung, A., Meng N. 2009. Integrating chemical kinetics with CFD modeling for autothermal reforming of biogas, International journal of hydrogen energy, 34: 9076-9086.

13. Jalilnejad K., Amani J. 2017. CFD modeling of formaldehyde biodegradation in an immobilized cellbioreactor with disc-shaped Kissiris support, Biochemical Engineering Journal, 122: 47-59.

14. Biogas Fermenter mixing -CFD simualtion. https://www.youtube.com/watch?v=aTwcvMksaTc. (Erişim Tarihi: 11.01.2018).

15. Standard Methods for the examination of water and wastewater, 21st Edition, APHA, AWWA, WEF $2540 \mathrm{G}, 2005$.

16. Jingquing Y., Dong L., Yongming S., Guohui W., Zhenhong Y., Feng Z., Yao W. 2013. Improved biogas production from rice stra by co-digestion ith kitchen and pig manure, Waste Management, 33: 2653-2658.

17. Jingquing Y., Dong L., Yongming S., Guohui W., Zhenhong Y., Feng Z., Yao W. 2013. Improved biogas production from rice stra by co-digestion ith kitchen and pig manure, Waste Management, 33: 2653-2658.

18. Kimyasal oksijen ihtiyac1 (KOI). http://cevre.beun.edu.tr/dersnotu/cevrekimyasi2/koitayini.pdf. (Erişim Tarihi: 11.01.2018).

19. J. Patinvoh R., Osadolor O., ChandoliasIlona K., Horváth S., J. Taherzadeh M. 2017. Innovative pretreatment strategies for biogas production, Bioresource Technology, 224: 13-24. 
20. Rodríguez-Abalde A., Flotats X., Fernández B. 2017. Optimization of the anaerobic co-digestion of pasteurized slaughterhouse waste, pig slurry and glycerine, Waste Management, 61: 521-528. 